\title{
Kader Promosi Kesehatan Preventif Penyalahgunaan Napza
}

\section{Preventive Health Promotion Cadre of Drug Abuse}

\author{
Dhesi Ari Astuti ${ }^{1}$, Nurul Kurniati ${ }^{2}$ \\ Universitas Aisyiyah Yogyakarta, Yogyakarta, Indonesia \\ 1․ㅐesi stikesayo@yahoo.co.id, ${ }^{2}$ nurul.kurniati@,unisayogya.ac.id
}

Riwayat Artikel: Dikirim 15 Oktober 2019; Diterima 20 November 2020; Diterbitkan 30 November 2020

\begin{abstract}
Abstrak
Pengguna Narkoba di DIY sejak tahun 2008 sampai dengan 2015 mengalami peningkatan. Data Badan Narkotika Negara menyebutkan pengguna Narkoba tahun 2008 sebesar 2,72\%, tahun 2011 2,8\% dan 2015 sebesar 3,37\%. Tujuan kegiatan ini membentuk kader promosi kesehatan preventif Napza pada remaja. Metode pelaksanaan kegiatan dengan membentuk kader yang telah terlatih dan melakukan sosialisasi kepada remaja lainnya untuk motivasi tes Napza. Hasilnya terbentuk 15 kader atau juru pemantau dan tersosialisasi upaya preventif Napza sejumlah 46 remaja lainnya yang termotivasi tes narkoba. Luaran dari kegiatan ini adalah selain terbentuknya kader dan remaja yang tersosialisasi dapat meningkatkan pengetahuan masyarakat terkait bahaya penyalahgunaan Napza.
\end{abstract}

Kata kunci: Juru Pemantau, Kader, Napza

\section{Abstract}

Drug users in DIY from 2008 to 2015 have increased. Data from the State Narcotics Agency said that drug users in 2008 were $2.72 \%$, in $20112.8 \%$ and 2015 were 3.37\%. The purpose of this activity is to form a cadre of preventive bealth promotion for adolescents. The method of implementing the activity is by forming cadres who bave been trained and conducting socialization to other teenagers to motivate drug tests. The result was formed 15 cadres or observers and socialized prevention efforts of 46 drug users who were motivated by drug testing. The output of this activity is in addition to the formation of cadres and adolescents who are socialized can increase public knowledge related to the dangers of drug abuse.

Keywords: Observer, Cadre, Napza

\section{PENDAHULUAN}

Penyalahgunaan Napza di dunia terus mengalami kenaikan dimana hampir $12 \%$ $(15,5$ juta jiwa sampai dengan 36,6 juta jiwa) dari pengguna adalah pecandu berat. Menurut World Drug Report tahun 2012, produksi Napza meningkat salah satunya diperkirakan produksi opium meningkat dari 4.700 ton di tahun 2010 menjadi 7.000 ton di tahun 2011 dan menurut penelitian yang sama dari sisi jenis narkotika, ganja menduduki peringkat pertama yang disalahgunakan di tingkat global dengan angka prevalensi 2,3\% dan 2,9\% per tahun (Andriyani, 2011).

Wilayah Sleman telah membentuk 5 satgas Narkoba, kelima desa yang akan memiliki Satgas Anti narkoba tahun ini meliputi Desa Bokoharjo, Prambanan, Kalitirto (Berbah), Caturharjo (Sleman), Margodadi (Sayegan) dan Sumbersari (Moyudan). Keberadaan Satgas Antinarkoba tersebut bertujuan untuk memproteksi wilayah tersebut dari ancaman narkoba melengkapi 23 Satgas yang telah terbentuk sebelumnya. Namun saat ini untuk Dusun Ngaran yang merupakan wilayah Kabupaten Sleman, belum termasuk dalam wilayah yang memiliki Satgas Narkoba (Harian Jogja, 2016).

Berdasarkan hasil penelitian Astuti (2012) Dusun Ngaran keberadaannya dekat dengan Jalan Wates yang merupakan wilayah hotspot Wanita Pekerja Seks Tidak Langsung (WPSTL), sehingga merupakan wilayah yang berisiko karena peredaran 
Narkoba erat kaitannya dengan seks dan HIV/AIDS. Belum ada pembinaan secara rutin ke dusun oleh petugas kesehatan setempat berkaitan masalah Napza. Ada satu organisasi yang dibentuk di masyarakat yaitu perkumpulan pemuda pemudi karang taruna Dusun Ngaran, Gamping.

Karang taruna dusun Ngaran mempunyai potensi yang besar untuk dikembangkan, dengan jumlah anggota 15 anggota dan aktivitas yang dilakukan secara rutin setiap bulan serta keaktifan dalam peningkatan rasa nasionalisme melalui acara peringatan hari kemerdekaan ataupun hari kebangkitan nasional.

Remaja di wilayah Dusun Ngaran memiliki beragam karakter dan latar belakang social budaya. Berkaitan dengan arus informasi yang ada saat ini sangat memungkinkan pengaruh baik positif dan negative mengenai pergaulan remaja. Dalam hal ini kegiatan yang sudah dilaksanakan remaja di dusun cukup banyak namun belum terfokus pada penyalahgunaan Napza dimana saat ini sangat beresiko terpapar. Hal ini dikarenakan minimnya informasi dan emosional kematangannya yang masih labil sehingga memungkinkan mempengaruhi kehidupan remaja. Beberapa hasil identifikasi permasalahan mitra yang ditemui dari hasil analisis situasi antara lain:

1. Minimnya informasi tentang bahaya Napza dan perkembangan tipe Napza dalam kurun waktu sekarang yang masuk ke Indonesia.

2. Penyuluhan kesehatan tentang bahaya Napza belum dipahami secara utuh oleh masyarakat luas karena belum adanya kader khusus.

\section{METODE}

Metode pelaksanaan kegiatan untuk menyelesaikan permasalahan adalah dengan menyusun buku panduan yang akan digunakan Remaja Pemantau Penyalahgunaan Narkoba. Melakukan pelatihan Kader Promosi Kesehatan Preventif Penyalahgunaan Narkoba dengan menghadirkan fasilitator konselor untuk selanjutnya kader Penyalahgunaan Narkoba dapat melakukan kunjungan ke rumah untuk melakukan deteksi dini dan memotivasi masyarakat untuk melakukan tes narkoba.

\section{HASIL DAN PEMBAHASAN}

Napza (narkotika, psikotropika, dan bahan adiktif lainnya) merupakan sekelompok obat, yang berpengaruh pada kerja tubuh, terutama otak. Napza dapat menimbulkan ketergantungan apabila dipergunakan tanpa adanya pengendalian, meskipun di sisi lain merupakan obat atau bahan yang bermanfaat di bidang pengobatan, pelayanan kesehatan, dan pengembangan ilmu pengetahuan. Penyalahgunaan Napza adalah penggunaan salah satu atau beberapa jenis Napza secara berkala atau teratur diluar indikasi medis, sehingga menimbulkan gangguan kesehatan fisik, psikis dan gangguan fungsi sosial (Azmiyati, 2014).

Alasan-alasan lain kenapa banyak remaja atau khususnya mahasiswa menyalahgunakan Napza misalnya, adanya rasa ingin tahu, tekanan teman sebaya, menentang orang tua, pelarian dari masalah, memberontak terhadap otoritas masyarakat (Hurlock 1994). Ada beberapa ciri kepribadian yang berisiko tinggi untuk menyalahgunakan Napza, anatara lain mudah kecewa, tidak sabaran, sifat suka memberontak, suka mengambil risiko, mudah bosan atau jenuh, dan kebanyakan memiliki tingkat religiositas yang rendah, serta memiliki harga-diri yang rendah.

Sikap remaja yang ingin tahu dan riskan terhadap coba-coba maka perlu diberikan pemahaman yang benar tentang Napza, sebab jika remaja terlanjur terjerumus maka akan sulit untuk keluar dari pengaruh Napza. Remaja yang telah terjerumus kemudian mendapatkan rehabilitasi pada umumnya juga akan kembali terjerumus karena minimnya rasa kepercayaan diri dari pengguna Napza dan bagaimana proses penerimaan teman sebaya kepada pecandu Napza ataupun mantan pecandu Napza. 
Kader atau dalam hal ini disebut Juru Pemantau adalah istilah umum Kader merupakan tenaga masyarakat yang dianggap paling dekat dengan masyarakat. Kementerian kesehatan membuat kebijakan mengenai pelatihan untuk kader yang dimaksudkan untuk meningkatkan pengetahuan, menurunkan angka kematian ibu dan anak kematian bayi. Pada kader kesehatan masyarakat itu seyogyanya memiliki latar belakang pendidikan yang cukup sehingga memungkinkan karena untuk membaca, menulis, dan menghitung secara sederhana (Nugroho, 2009). Rencana kegiatan yang akan dilaksanakan adalah: Penyusunan buku dan leaflet sebagai pegangan untuk Kader Promosi Kesehatan, menentukan Kader yang dipilih dari anggota kelompok Karang Taruna Dusun Ngaran Gamping, mengadakan pelatihan Kader Promosi Kesehatan Napza. Pelaksanaan kegiatan berupa kunjungan kader ke rumahrumah warga dan memberikan informasi terkait Napza, sehingga menumbuhkan motivasi untuk melakukan tes Napza. Kader promosi kesehatan Napza harus melakukan kunjungan ke rumah-rumah setiap bulan.

Hasil dari kegiatan ini terbentuknya 15 Juru Pemantau Tes Napza, tersusunnya buku panduan deteksi dini Napza, meningkatnya pengetahuan dan ketrampilan kader promosi kesehatan dalam melakukan deteksi dini pengguna Napza. Setiap kader dapat menumbuhkan motivasi untuk melakukan tes Napza pada 5 teman sebaya, sehingga akan ada 46 orang yang termotivasi melakukan tes Napza.

\section{Gambar 1.}

Kegiatan Sosialisasi kepada Kader

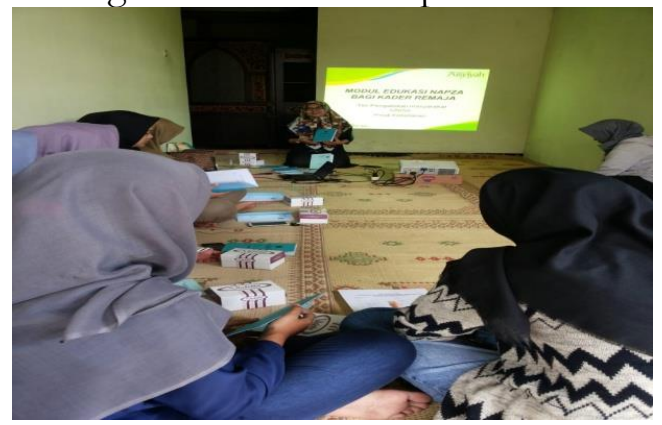

Sumber: Dokumentasi Pribadi
Gambar 2.

Kegiatan Simulasi kader preventif Napza

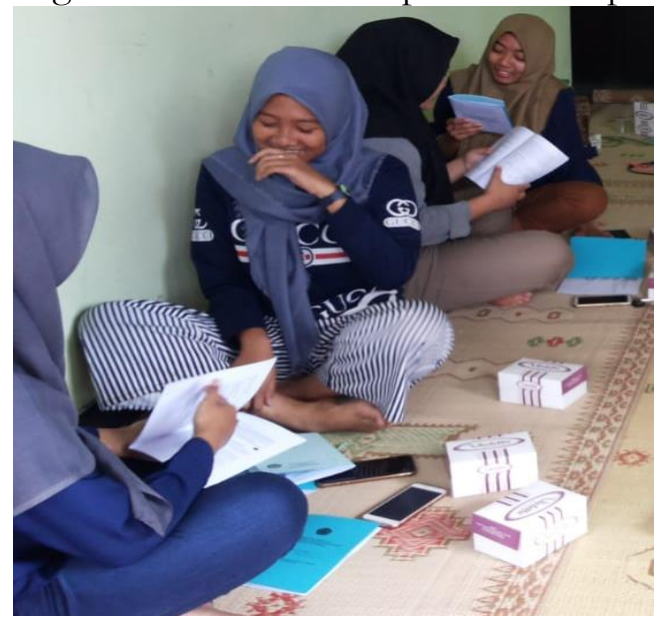

Sumber: Dokumentasi Pribadi

Gambar 3.

Media Simulasi kader preventif Napza

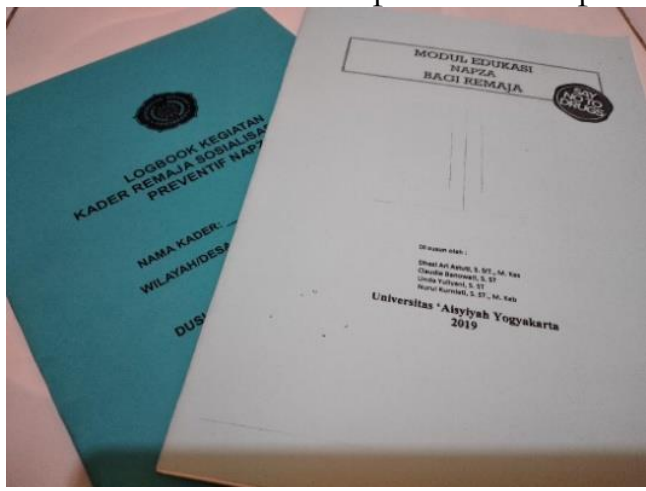

Sumber: Dokumentasi Pribadi

\section{KESIMPULAN}

Berdasarkan analisis situasi dan kegiatan pengabdian masyarakat yang dilakukan telah dibentuk kader atau juru pemantau Napza dilingkungan Dusun Ngaran sejumlah 15 kader dan telah tersosialisasi 46 remaja lainnya untuk termotivasi melakukan tes skrining preventif Napza.

\section{DAFTAR PUSTAKA}

Astuti, Dhesi. (2012). Faktor-faktor yang Mempengarubi Perilaku WPSTL Melakukan VCT di Kabupaten Bantul. STIKES Aisyiyah Yogyakarta: Yogyakarta.

Azmiyati, S. R. (2014). Gambaran penggunaan Napza pada anak jalanan di Kota Semarang. KEMAS: Jurnal 
Kesebatan Masyarakat, 9(2), 137-143.

Badan Penelitian dan Pengembangan Kesehatan Kementerian Kesehatan RI. (2010). Riset Kesehatan Dasar. Jakarta.

Hurlock, E. (1994). Psikologi Perkembangan: Suatu Pendekatan Sepanjang Rentang Kehidupan. Jakarta: Erlangga

Muhaimin, T. (2011). Prevalensi HIV pada ibu hamil di delapan ibu kota provinsi di Indonesia tahun 2003-2010. Makara Journal of Health Research, 15(2). Nurdiana, D. (2009). Hubungan Antara Pengetahuan dan Motivasi Kader Posyandu dengan Keaktifan Kader Posyandu di Desa Dukuh Tengah Kecamatan Ketanggungan Kabupaten Brebes.

Pecandu Narkoba di Yogyakarta Diprediksi Naik - Nasional Tempo.co. Diakses dari https://nasional.tempo.co/read/457 472/pecandu-narkoba-di-yogyakartadiprediksi-naik.

Penyalahgunaan Narkoba 5 Desa di Sleman Bentuk Satgas Antinarkoba. Diakses dari http://m.harianjogja.com/baca/201 6/03/16/penyalahgunaan-narkoba5-desa-di-sleman-bentuk-satgasantinarkoba. 